R. T. TAYLOR ET AL.: GASTRIC- ULCERATION DURING INDOMETHACIN THERAPY

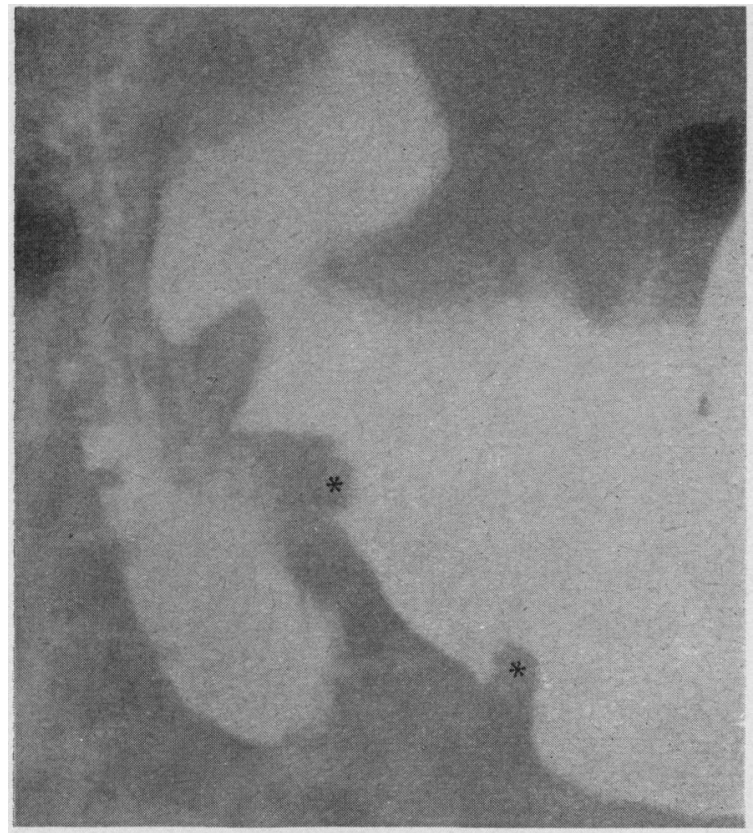

FIG. 1 (a)

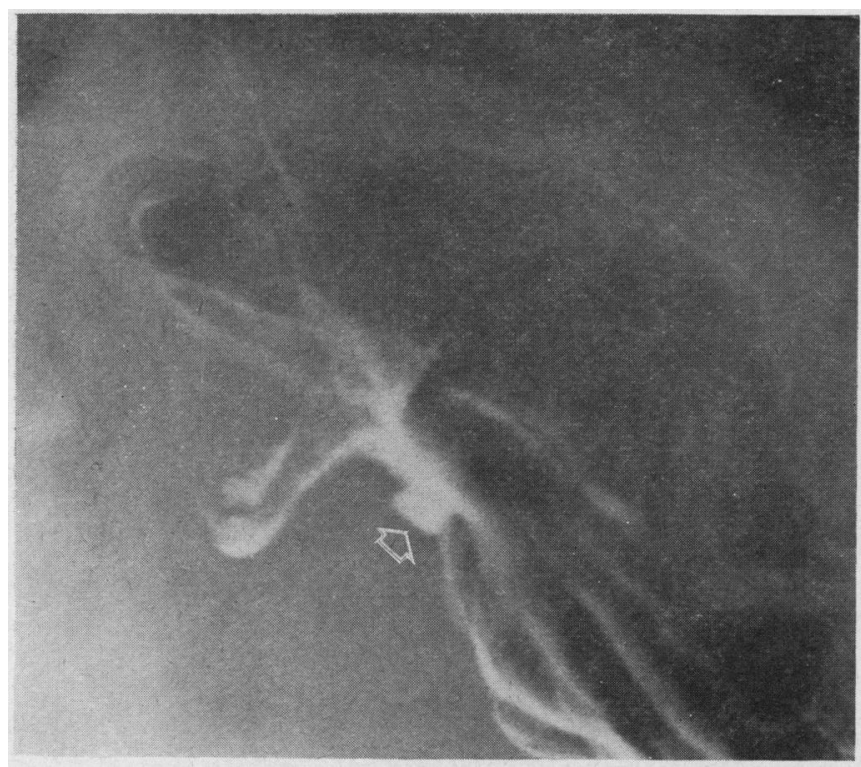

FIG. 2 (a)

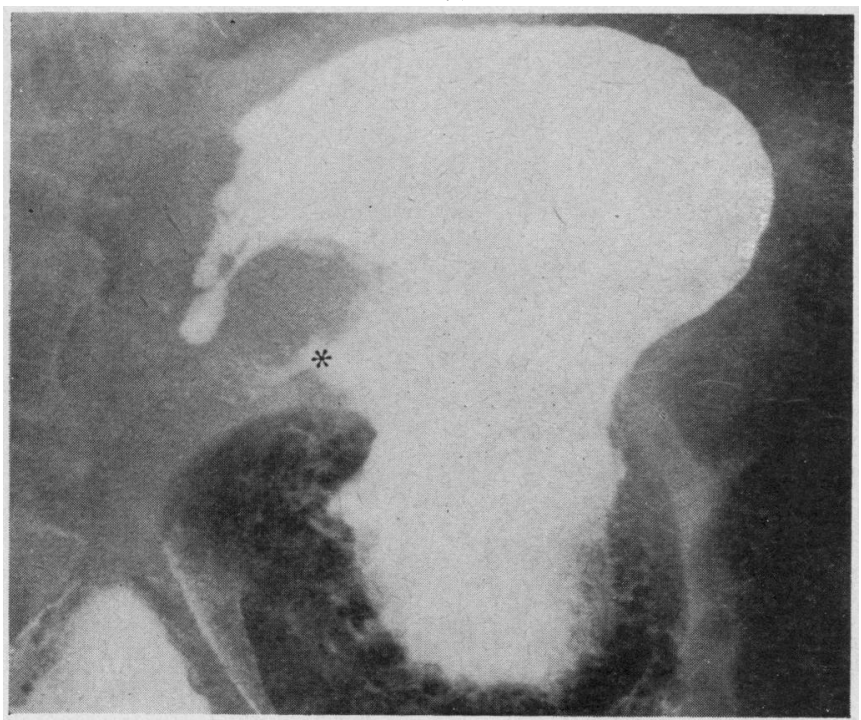

FIG. 2 (c)
FIG. 1.-Case 3. (a) Wide shallow ulcer with "rolled" edges $\left(^{*}\right)$ on the greater curve aspect of the propyloric region. (b) The months later. Healing is progressing.

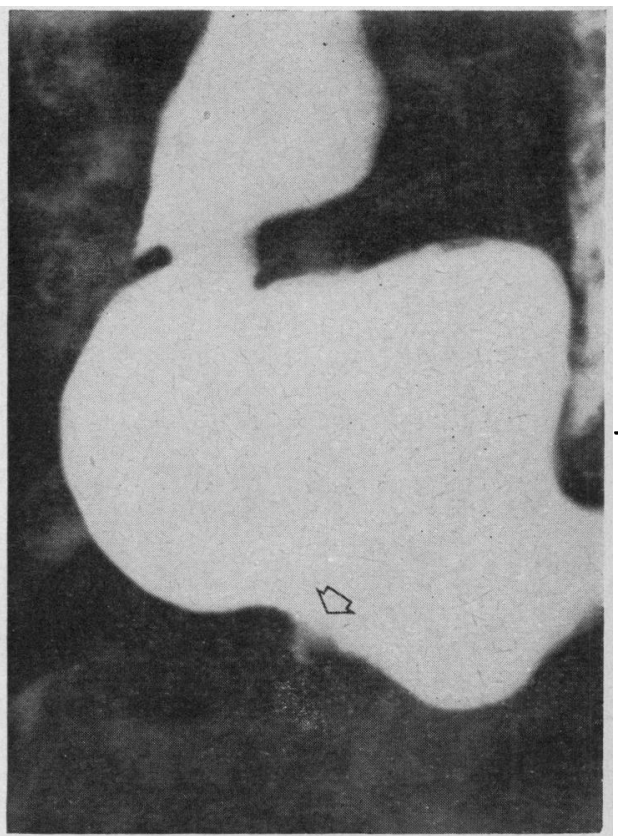

FIG. 1 (b)

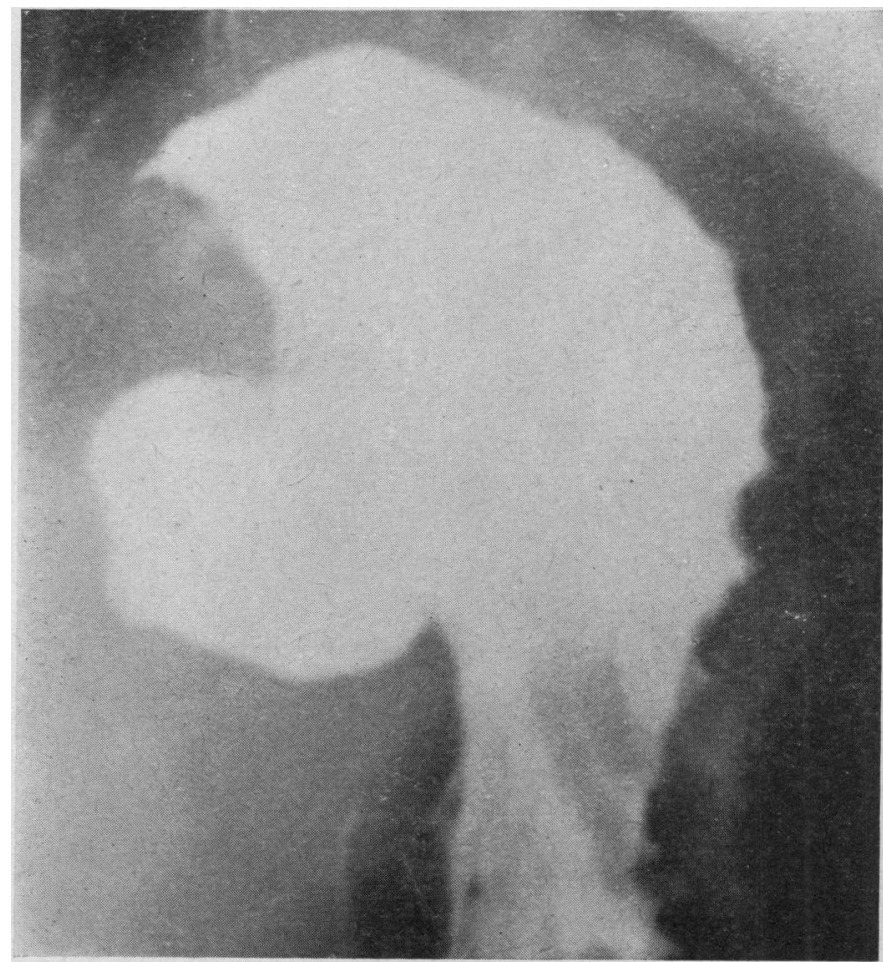

FIG. 2 (b)

Fig. 2.-Case 10. (a) Small ulcer high on the lesser curve of the stomach two years before indomethacin treatment was started. (b) Giant ulcer present after 18 months' indomethacin treatment. (c) The ulcer was completely healed seven months later, leaving a scarred and deformed lesser curve. *Indicates position where the oesophagus enters the 
angiographic grounds embolectomy should be considered. Alternatively, continued streptokinase and/or heparin therapy is justified if the obstruction is predominantly distal rather than proximal or if recent cardiac infarction is suspected. Pulmonary embolectomy may be necessary in patients whose circulation is failing rapidly or if conservative measures, including streptokinase and isoproterenol infusion, fail to restore and maintain a satisfactory circulation at any time following diagnosis. Although pulmonary embolectomy may be lifesaving, the indications for operation are of ten complicated by the fact that many patients are elderly and have associated cardiac or pulmonary disease.

This investigation was supported by a grant from the National Heart Foundation of Australia. Exercise studies were made possible by a grant from the St. Vincent's School of Medical Research. We are grateful to the medical, nursing, and technical staff of St. Vincent's Hospital, to Mr. J. K. Clarebrough, thoracic surgeon, St. Vincent's Hospital, and to Mr. K. N. Morris, honorary thoracic surgeon, Alfred Hospital, for their assistance and co-operation; also to Professor G. C. de Gruchy for constructive comments. The streptokinase (Streptase) was kindly supplied by Australian Hoechst Limited.

Requests for reprints should be sent to J. Hirsh, University Department of Medicine, St. Vincent's Hospital, Fitzroy, Victoria, Australia 3065.

\section{REFERENCES}

Browse, N. L., and James, D. C. O. (1964). Lancet, 2, 1039.

Chait, A., Summers, D., Krasnow, N., and Wechsler, B. M. (1967) Amer. ₹. Roentgenol., 100, 364

Comroe, J. H., Forster, R. E., Dubois, A B., Briscoe, W. A., and Carlsen, E. (1962). The Lung : Clinical Phvsiology and Pulmonary Function Tests, 2nd ed. Chicago.

Emanuel, D. A., Sautter, R. D., and Wenzel, F. J., (1966). F. Amer. med Ass., 197, 924.

Fred, H. L., Axelrad, M. A., Lewis, J. M., and Alexander, J. K. (1966). f. Amer. med. Ass., 196, 1137.

Genton, E. and Wolf, P S (1967a), 7. Lab. clin. Med, 70, 311.

Genton, E., and Wolf, P. S. (1967b). Circulation, 35, Suppl. No. 2

Hirsh, J., Hale, G. S., McDonald, I. G., McCarthy, R. A., and Cade,

Jollister, L. E., and Cull, V. L. (1956). Amer F. Med., 21, 312.

Johnson, A. J., and McCarty, W. R. (1959). Y. clin. Invest., 38, 1627

McDonald, I. G, Hirsh, J., Hale, G. S., Cade, J. F., and McCarthy, R. A (1968). Med. . Aust. In press.

Orell, S. R. (1962). Acta med. scand., 172, 473.

O'Sullivan, E. F., Hirsh, J., McCarthy, R. A., and de Gruchy, G. C. (1968). Med. \%. Aust., 2, 153.

Rosenberg, D. M. L., Pearce, C, and McNulty, J. (1964). F. thorac. cardiovasc. Surg., 47, 1

Sasahara, A. A., Cannilla, J. E., Belko, J. S., Morse, R. L., and Criss, A. J. (1967). New Engl. F. Med., 277, 1168.

Sautter, R. D., Emanuel, D. A., and Wenzel, F. J. (1967). Ann. thorac Surg., 4, 95 .

Schmutzler, R., et al. (1966). Germ. med. Mth., 11, 308.
Thomas, D. P. (1965). New Engl. f. Med., 273, 885.

Tillett, W. S., Johnson, A. J., and McCarty, W. R. (1955). f. clin.

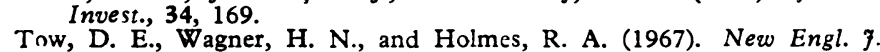
Med., 277, 1161 .

Verstraete, M., Vermylen, J., Amery, A., and Vermylen, C. (1966). Brit. med. F., i, 454.

\title{
Gastric Ulceration Occurring during Indomethacin Therapy*
}

\author{
R. T. TAYLOR, M.B., M.R.C.P. ; E. C. HUSKISSON, M.B., M.R.C.P. ; G. H. WHITEHOUSE, M.B., M.R.C.P. \\ F. DUDLEY HART, M.D., F.R.C.P. ; D. H. TRAPNELL, M.A., M.D., M.R.C.P., F.F.R.
}

[With Special Plate Between Pages 732 and 733]

Cummary : Dyspeptic symptoms, gastrointestinal bleed$\checkmark$ ing, or the development of anaemia without dyspepsia in patients treated with indomethacin may be manifestations of peptic ulceration. Such manifestations occur with suppositories as well as with capsules. The ulcers in the present series tended to be prepyloric, and often aroused the suspicion of malignancy. Symptoms were promptly relieved and radiological healing occurred rapidly after withdrawal of the drug.

\section{Introduction}

Indigestion and occasional peptic ulceration are side-effects that may occur during indomethacin therapy (Lövgren and Allander, 1964 ; Lockie and Norcross, 1966 ; Boardman and Hart, 1967). Hart (1965) drew attention to the occurrence of gastric ulceration with radiological features suggesting malignancy, and we here report seven such cases that have occurred in patients receiving indomethacin. Three other cases of gastric ulceration are also reported and discussed.

\section{Case 1}

\section{Case Reports}

A 51-year-old clerk had had rheumatoid arthritis since 1959. She was started on oral indumethacin in August 1967. Three

- From Westminster Hospital, London S.W.1. months later she developed headaches, dizziness, and pounding in the head, and stopped taking indomethacin. She was found to be anaemic (haemoglobin 60\%), and a barium meal examination revealed a prepyloric ulcer. She had had no indigestion at any time. One month after stopping indomethacin she was asymptomatic, and a barium meal examination showed complete healing of the ulcer. She remained symptom-free six months later.

\section{Case 2}

A 48-year-old shopkeeper had had rheumatoid arthritis since 1964. He was started on oral indomethacin in May 1965, and continued taking 150-250 mg. daily for two years. In May 1967 he was admitted to hospital as an emergency case, having vomited a large amount of blood. One month previously he had developed epigastric pain, but had been unable to reduce the dosage of indomethacin because of increasing stiffness. He had had no indigestion before this time. A barium meal examination showed a shallow prepyloric ulcer. He was given no further indomethacin by mouth, but was started on suppositories (100 mg. twice daily). A barium meal examination one month later showed only a very shallow crater. A further barium meal examination in September 1967 showed the ulcer to be larger. The appearance was said to be suspicious of malignancy. Indomethacin suppositories were withdrawn, and three months later the ulcer was completely healed. He remained symptom-free six months later.

\section{Case 3}

A 61-year-old electrical inspector was admitted to hospital in September 1965, having had rheumatoid arthritis for 14 months. 
Treatment was started w.th indomethacin $125 \mathrm{mg}$. by mouth daily, and from October to December he also received prednisone $5 \mathrm{mg}$. daily. Oral indomethacin only, 150-250 mg. daily, was continued through 1966 and 1967. In October 1967 he complained of epigastric pain, anorexia, and loss of $5 \mathrm{lb}$. $(2,270 \mathrm{~g}$.) in weight. A barium meal examination (Special Plate, Fig. 1a) showed a large shallow prepyloric ulcer. Intragastric photography (Dr. G. D. Hadley, Middlesex Hospital) showed the appearances of a benign ulcer. Indomethacin was withdrawn, and he was given flufenamic acid and antacids. His symptoms improved rapidly, and a barium meal examination 10 weeks later showed considerable healing of the ulcer. A further barium meal examination in March 1968 showed that healing had continued (Special Plate, Fig. 1b). In June he again complained of epigastric pain, and another barium meal examination showed that the ulcer had enlarged.

\section{Case 4}

A 64-year-old woman had had rheumatoid arthritis since 1942 for which she was receiving corticotrophin. She was started on oral indomethacin in May 1967 and the corticotrophin was gradually reduced. In September she complained of vomiting, and indomethacin suppositories were substituted with temporary benefit. In October she was admitted to hospital because her general condition had deteriorated considerably. She was stiff, unable to walk, and very depressed. She had again been vomiting, with nausea and anorexia. Onset of these symptoms coincided with cessation of corticotrophin, and her state was attributed to lack of steroid. Though her general condition improved with rest, she continued to vomit, and a barium meal examination was therefore made, which showed a prepyloric ulcer. Indomethacin suppositories were discontinued. A barium meal examination one month later showed complete healing, and she had no further gastric symptoms. Seven months later she was symptom-free.

\section{Case 5}

A 63-year-old retired bank manager was admitted to hospital in April 1965 because of a superficial calf-vein thrombosis. His symptoms subsided with rest alone. He had also had rheumatoid arthritis for five months, and treatment for this was started with indomethacin $75 \mathrm{mg}$. by mouth daily. This was increased to 125 mg. daily with good effect. After discharge he had further pain in the calf with swelling of the leg. He was readmitted and given anticoagulants (phenindione). Indomethacin was continued. On 3 June he passed two melaena stools. He had had only occasional heartburn up to this time. His prothrombin times had not been greater than 34 seconds (control 13 seconds) since anticoagulants were started, but phenindione was stopped and vitamin $\mathrm{K}$ given. A barium meal examination on 9 June showed a pyloric ulcer. As it was felt that this was likely to be malignant, he was readmitted for laparotomy and gastrectomy. Indomethacin was reduced to $25 \mathrm{mg}$. daily. He was given antacids and propantheline. Laparotomy was postponed at the last moment, as it was thought that indomethacin might be responsible for the ulcer. A barium meal examination on 21 July showed that the ulcer had almost healed. His progress since then has been uneventful and entirely satisfactory.

\section{Case 6}

A 76-year-old housewife was admitted to hospital with a six-weeks history of increasing epigastric pains and flatulence, later complicated by nausea and vomiting. She had had rheumatoid arthritis for many years. Eighteen months before admission she was started on indomethacin $100 \mathrm{mg}$. by mouth daily, but because of increasing joint pain and disability she had raised the dose to $150 \mathrm{mg}$. daily. She was found to be anaemic, with occult blood in the faeces, and a barium meal examination revealed a large incarcerated hiatus hernia and two gastric ulcers, one at the level of the hernia and another on the lesser curve aspect of the prepyloric region. She was treated with carbenoxolone, and indomethacin was withdrawn. Within one month the upper gastric ulcer had healed completely and the lower one had almost disappeared. Nine months later she was symptom-free.

\section{Case 7}

A 48-year-old dental surgeon had had gout for 20 years. In August 1964 he first received indomethacin, $100 \mathrm{mg}$. by mouth daily. In March 1965 the dose was reduced to $75 \mathrm{mg}$. and then to $50 \mathrm{mg}$. daily. In June 1965 he complained of postprandial epigastric pain, and a barium meal examination showed a large posterior-wall gastric ulcer that was thought to be malignant. Gastrectomy was performed, and histology showed that it was benign.

\section{Case 8}

A 40-year-old lorry driver with a 12-years history of ankylosing spondylitis was started on oral indomethacin in December 1964. In May 1966 he complained of tiredness, and his haemoglobin was found to be $50 \%$. Subsequent barium meal examination showed a large ulcer high on the lesser curve of the stomach. He had had no indigestion. Five months later he was started on indomethacin suppositories, but a further barium meal examination was not carried out until February 1967. This showed that the ulcer was smaller. Indomethacin suppositories were stopped in March 1968, and one month later the ulcer was found to be healed. He remained well four months later.

\section{Case 9}

A 93-year-old woman developed pains in the back, for which she was given oral indomethacin. Radiographs showed some collapse of the body of the ninth thoracic vertebra, probably due to osteoporosis. She had had no indigestion. Seven weeks later she was admitted to hospital having had a massive haematemesis and melaena. She rapidly became comatose and died the same day. Necropsy revealed a benign gastric ulcer, approximately $1 \mathrm{~cm}$. in diameter, in the posterior part of the stomach.

\section{Case 10}

A 68-year-old man had had epigastric pain after meals for 16 years. A series of barium meal examinations over 12 years had shown a small ulcer high on the lesser curve of the stomach (Special Plate, Fig. 2a). He had also had ankylosing spondylitis for many years, and when this became increasingly painful he was started on indomethacin $75 \mathrm{mg}$. by mouth daily. After 18 months of this treatment his epigastric pains increased and he becsme anaemic (haemoglobin $45 \%$ ), with occult blood in the faeces. A barium meal examination at this time showed a giant ulcer (Special Plate, Fig. 2b) at the site of the previous small one. He was treated with carbenoxolone, the indomethacin being withdrawn. His symptoms improved, and a barium meal examination four months later showed that the ulcer was much smaller. Seven months later it had disappeared completely (Special Plate, Fig. 2c). He had no symptoms when seen three months later.

\section{Discussion}

In the early animal work on indomethacin gastrointestinal toxic effects rapidly became evident. Mucosal ulceration occurred in different species in different sites-in the large intestine in the monkey and domestic pig, and in the small intestine in most other species. These lesions were dose-related and in the dog could be produced when the drug was given by oral, intravenous, or rectal routes.

Man has apparently fared better than other species, but Lövgren and Allander (1964) reported a series of 18 patients receiving indomethacin 200-300 mg. daily. Five developed "gastroduodenal" ulcers and two of them died, one after massive haemorrhage from a large gastric ulcer and one after resection of multiple gastric ulcers. Three of these five patients had a previous history of gastric or duodenal ulcers, but barium meal examinations were negative at the onset of the treatment with indomethacin. Lockie and Norcross (1966) noted 14 peptic ulcers in their series of 180 patients on indomethacin. 
Eight of these patients had had previous ulcers, and 11 had also been on salicylates or steroids. In this series there were five perforations and seven haemorrhages from the ulcers.

Boardman and Hart (1967), reviewing the side-effects of indomethacin, found that dyspepsia occurred in 18 out of 228 patients $(7.8 \%)$. However, this side-effect was not dose-related, unlike headache and giddiness. Dyspepsia tended to occur in patients who had experienced it from chemically unrelated drugs, such as phenylbutazone and oxyphenbutazone.

In the present series gastric ulcer developed in 10 patients on indomethacin. Our interest in this possible complication was stimulated by the observation of prepyloric ulceration with suspicion of malignancy, which had in one case led to gastrectomy for a benign ulcer, while in another case healing occurred on withdrawal of indomethacin. During a nine-month period barium meal examinations were carried out on all patients attending our rheumatism clinic with recent onset of dyspepsia or anaemia. During this time four were negative and five gastric ulcers were found in patients on indomethacin. These five, and five discovered previously or at another hospital, comprise the present series. No gastric ulcers were found in patients attending the clinic during the same period who were receiving other drugs, though these were in the majority.

The ulcers occurred from two months to two years after the start of indomethacin, and the total dose varied from 4 to $150 \mathrm{~g}$. Nine of the 10 patients had no past history of dyspepsia. One patient (Case 10, Fig. 2) had a previous history of gastric ulceration. During indomethacin therapy his ulcer increased in size and he became anaemic. Healing occurred when indomethacin was withdrawn and carbenoxolone given.

Other drugs known to cause gastric ulceration were conspicuously absent. One patient (Case 6) was receiving aspirin in the period before the ulcer appeared. None of the patients had had phenylbutazone, oxyphenbutazone, or cortisone or its analogues. One patient (Case 4) had had corticotrophin. In five patients (Cases 1, 2, 3, 4, and 8) healing occurred with no treatment other than antacids and withdrawal of indomethacin. In Case 5 indomethacin was reduced to $25 \mathrm{mg}$. daily, and healing took place. Carbenoxolone was also used in Cases 6 and 10. Only one patient was in hospital during the period of ulcer-healing. None of the patients received advice about smoking. In two cases evidence of healing was not available: one had a gastrectomy and one died.

Seven patients, those in whom the ulcer healed completely after withdrawal of indomethacin, have remained symptomless for periods of four months to three years. In one patient (Case 3 ) in whom the ulcer did not heal completely a recurrence occurred after nine months.

In three patients (Cases 2, 4, and 8) gastric ulceration was demonstrated while the patient was on suppositories alone, and healing occurred when they were discontinued. In case 2 the ulcer enlarged while the patient was receiving only suppositories.

That the ulcers were related to indomethacin therapy was suggested by their rapid healing when the drug was withdrawn, though proof of cause and effect is certainly not established by this small series. The incidence of peptic ulceration in rheumatoid arthritis has been variously reported as $4.1 \%$ of 244 patients by Baragar and Duthie (1960), 18.2\% of men and $8.7 \%$ of women by Kern, Clark, and Lukens (1957), and $5.6 \%$ of 357 patients by Short, Bauer, and Reynolds (1957). The last concluded that peptic ulceration was at least as common in rheumatoid arthritis as in the general population, though no figures from a control group are available. Gibberd (1966) reported that $30(5.6 \%)$ of 533 patients attending our rheumatism clinic over an 11-year period had peptic ulcers, of whom $13(2.4 \%)$ were gastric. Though aspirin, phenylbutazone, and steroids increased the incidence of dyspepsia they did not appear to be a factor in producing peptic ulceration. Indomethacin may be a factor, and many ulcers may pass unnoticed, since it is usual to withdraw the drug when dyspepsia occurs; barium meal examination is not usually considered necessary in this situation.

The presenting features are shown in Table I. Seven patients presented with haematemesis, melaena, or anaemia, and three of these had no indigestion.

\begin{tabular}{|c|c|c|c|c|c|c|}
\hline Case & $\begin{array}{l}\text { Age } \\
\text { and } \\
\text { Sex }\end{array}$ & Diagnosis & $\begin{array}{l}\text { Approx. } \\
\text { Total } \\
\text { Indo- } \\
\text { methacin }\end{array}$ & $\begin{array}{c}\text { Duration } \\
\text { of } \\
\text { Indo- } \\
\text { methacin }\end{array}$ & $\begin{array}{l}\text { Presen- } \\
\text { tation }\end{array}$ & $\begin{array}{l}\text { Other } \\
\text { Drugs }\end{array}$ \\
\hline 1 & $51 \mathrm{~F}$ & Rheumatoid & $10 \mathrm{~g}$. & 3 months & Anaemia & Paracetamol \\
\hline 2 & $48 M$ & $\begin{array}{c}\text { Rheumatoid } \\
\text { arthritis }\end{array}$ & $150 \mathrm{~g}$. & 2 years & $\begin{array}{c}\text { Epigastric } \\
\text { pain. } \\
\text { Haema- } \\
\text { temesis }\end{array}$ & $\begin{array}{c}\text { Paracetamol. } \\
\text { Ferrous } \\
\text { gluconate }\end{array}$ \\
\hline 3 & $61 M$ & $\begin{array}{c}\text { Rheumatoid } \\
\text { arthritis }\end{array}$ & $145 \mathrm{~g}$. & 2 years & $\begin{array}{c}\text { Epigastric } \\
\text { pain. } \\
\text { Anorexia }\end{array}$ & None \\
\hline 4 & $64 \mathrm{~F}$ & $\begin{array}{c}\text { Rheumatoid } \\
\text { arthritis }\end{array}$ & $16 \mathrm{~g}$. & 6 months & $\begin{array}{c}\text { Anorexia. } \\
\text { Vomiting }\end{array}$ & $\begin{array}{l}\text { Corticotrophin. } \\
\text { Dextropropoxy- } \\
\text { phene. } \\
\text { Paracetamol. } \\
\text { Perphenazine. } \\
\text { Dihydrocodeine } \\
\text { Ferrous gluco- } \\
\text { nate. Frusemide. } \\
\text { Slow-K }\end{array}$ \\
\hline 5 & $63 \mathrm{M}$ & $\begin{array}{c}\text { Rheumatoid } \\
\text { arthritis }\end{array}$ & $9 \mathrm{~g}$. & 2 months & Melaena & $\begin{array}{l}\text { Mersalyl. } \\
\text { Chlorothiazide. } \\
\text { Phenindione }\end{array}$ \\
\hline 6 & $76 \mathrm{~F}$ & $\begin{array}{c}\text { Rheumatoid } \\
\text { arthritis }\end{array}$ & $57 \mathrm{~g}$. & 18 months & $\begin{array}{l}\text { Epigastric } \\
\text { pain. } \\
\text { Vomit- } \\
\text { ing. } \\
\text { Anaemia } \\
\text { Epigastric }\end{array}$ & $\begin{array}{l}\text { Dextropropoxy- } \\
\text { phene. } \\
\text { Phenacetin. } \\
\text { Aspirin. } \\
\text { Caffeine } \\
\text { Probenecid }\end{array}$ \\
\hline 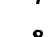 & $40 \mathrm{M}$ & Godt & & 10 wontis & pain & None \\
\hline 8 & $40 \mathrm{M}$ & $\begin{array}{l}\text { Ankylosing } \\
\text { spondylitis }\end{array}$ & $34 \mathrm{~g}$. & 18 months & Anaemia & None \\
\hline 9 & $93 \mathrm{~F}$ & Osteoporosis & $4 \mathrm{~g}$. & 7 weeks & $\begin{array}{c}\text { Haema- } \\
\text { temesis. } \\
\text { Melaena }\end{array}$ & None \\
\hline 10 & $68 M$ & $\begin{array}{c}\text { Ankylosing } \\
\text { spondylitis }\end{array}$ & $45 \mathrm{~g}$. & 18 months & $\begin{array}{l}\text { Exacerba- } \\
\text { tion of } \\
\text { ulcer } \\
\text { symptoms. } \\
\text { Anaemia }\end{array}$ & Alkalis \\
\hline
\end{tabular}

The radiological features of the ulcers in nine patients in whom barium meal examinations were performed are summarized in Table II.

TABLB II.-Radiological Peatures

\begin{tabular}{|c|c|c|c|c|}
\hline $\begin{array}{l}\text { Case } \\
\text { No. }\end{array}$ & $\begin{array}{l}\text { Site } \\
\text { of Ulcer }\end{array}$ & $\begin{array}{l}\text { Diameter of } \\
\text { Ulcer }(\mathrm{cm} .)\end{array}$ & $\begin{array}{c}\text { Projection } \\
\text { from } \\
\text { Stomach } \\
\text { Outline }\end{array}$ & $\begin{array}{c}\text { Course } \\
\text { after } \\
\text { Stopping } \\
\text { Indomethacin }\end{array}$ \\
\hline 1 & Prepyloric greater curve & 0.5 & Yes & Healed in \\
\hline 2 & Prepyloric lesser curve & $1 \cdot 3$ & Yes & Healed in \\
\hline 3 & Prepyloric greater curve & $4 \cdot 5$ & No & Partially healed \\
\hline 4 & Prepyloric lesser curve & 1 & Yes & Healed in \\
\hline 5 & Pyloric lesser curve .. & 1.8 & Yes & Almost healed \\
\hline 6 & Prepyloric lesser curve & 1.8 & Yes & $\begin{array}{l}\text { Almost healed } \\
\text { in } 1 \text { month }\end{array}$ \\
\hline & High lesser curve $\quad$. & 1.5 & Slightly & $\begin{array}{l}\text { Healed in } \\
1 \text { month }\end{array}$ \\
\hline $\begin{array}{l}7 \\
8\end{array}$ & $\begin{array}{ll}\text { High posterior wall } & \ldots \\
\text { High lesser curve } & \ldots\end{array}$ & $\begin{array}{l}5 \\
2 \cdot 5\end{array}$ & $\begin{array}{l}\text { Yes } \\
\text { Yes }\end{array}$ & $\begin{array}{l}\text { Gastrectomy } \\
\text { Healed in }\end{array}$ \\
\hline 10 & High lesser curve & 5 & Yes & $\begin{array}{l}\text { Healed in } 7 \\
\text { months with } \\
\text { residual } \\
\text { scarring }\end{array}$ \\
\hline
\end{tabular}

The suspicion that the gastric ulcer demonstrated was a malignant one was aroused at some stage in seven of our cases. Case 5 was " rescued" from operation at the last moment. Case 7, occurring at about the same time, underwent gastrectomy because the ulcer was thought to be malignant, but it was, in fact, benign.

The radiological diagnosis of malignant and benign gastric ulcers is notoriously difficult. Many different criteria have 
been described to make possible this distinction, but none is reliable (Trapnell, 1967). Some of the radiological features in this series are given in Table II. According to Shanks (1958), any gastric ulcer with a diameter of more than $2.5 \mathrm{~cm}$. should be regarded as being malignant until proved otherwise. However, Jennings and Richardson (1954) stress that giant ulcers are often benign, and Kemp Harper and Green (1961) found that an ulcer of such dimensions is almost as frequently benign as malignant. Three of the present cases had ulcers with a diameter of $4.5-5 \mathrm{~cm}$.

The site of a particular gastric ulcer is an unreliable guide in distinguishing between those that are benign and those that are malignant, but Shanks (1958) found that malignant ulcers occurred most commonly on the lesser curve near the pylorus. Prepyloric and pyloric ulcers are regarded by most radiologists as at least potentially malignant. Six of the ulcers in our series were in this position. One of these was large and shallow with rolled edges, and did not project from the stomach outline (Case 3, Fig. 1). Projection from the stomach outline is probably the most reliable single radiological feature of a benign gastric ulcer (Trapnell, 1967). It is notable that all but one of our cases (No. 3) did project in this way.

We wish to thank Professor M. D. Milne for permission to report Case 5, and Dr. G. E. Hosking for Cases 6, 9, and 10. In addition, we are grateful to Dr. G. D. Hadley for gastric photography in Case 3.

\section{REFERENCES}

Baragar, F. D., and Duthie, J. J. R. (1960). Brit. med. 7., 1, 1106.

Boardman, P. L., and Hart, F. D. (1967). Ann. rheum. Dis., 26, 127.

Gibberd, F. B. (1966). Acta rheum. scand., 12, 112.

Haber, R. B. K, and Green, B. (1961). Clin. Radiol., 12, 95.

Hart, F. D. (1965). Brit. med. f., 2, 1000.

Hart, F. D. (1965). Brit. med. J., 2, 1000. Lancet, 2, 343.

Jennings, D., and Richardson, J. E. (1954). Lancet, 2, 343 .

33, 25.
Lockie, L. M., and Norcross, B. M. (1966). In Arthritis and Allied Conditions, 7 th ed., edited by J. L. Hollander, p. 345 . London.

Lövgren, O., and Allander, E. (1964). Brit. med. f., 1, 118.

Shanks, S. C. (1958). In $A$ Textbook of $X$-ray Diagnosis, 3rd ed., vol. 3, edited by S. C. Shanks and P. Kerley. London.

Short, C. L., Bauer, W., and Reynolds, W. E. (1957). Rheumatoid Arthritis. Cambridge, Massachusetts.

Trapnell, D. H. (1967). Principles of X-ray Diagnosis, p. 102. London.

\title{
Severe Gastrointestinal Haemorrhage: Haemangiomata Demonstrated by Selective Visceral Arteriography
}

\author{
E. C. ASHBY,* M.CHIR., F.R.C.S. ; T. J. MOTT, † F.R.C.S. ; F. STARER, $\ddagger$ M.R.C.P.ED., F.F.R.
}

[With Special Plate Facing Page 733]

\begin{abstract}
Cummary : Selective visceral arteriography was found to be invaluable in the management of two cases of severe gastrointestinal haemorrhage associated with cavernous haemangiomata (a large gastric haemangioma and a small jejunal haemangioma). It is suggested that arteriography may be indicated in cases where a previous laparotomy has not shown the cause of bleeding, when the patient's general condition precludes a prolonged operation, and when superficial haemangiomata are found.
\end{abstract}

\section{Introduction}

Conventional clinical methods often fail to show a cause for gastrointestinal haemorrhage. The failure rate has been of the order of $15-33 \%$ in some large series (Birke and Engstedt, 1956 ; Jones et al., 1959 ; Berkowitz, 1963). At operation the source of bleeding of ten remains obscure (Retzlaff et al., 1961).

Gastrointestinal haemorrhage of obscure origin may be due to haemangiomata much more frequently than is recognized, since these are difficult to find at operation. For instance, Rutter (1956) reported a case in which bleeding from the ascending colon was located at the third operation; only during pathological examination of the removed colon was a haemangioma found. It has been argued that the not infrequent success of "blind" partial gastrectomy may sometimes be due to removal of small unrecognized haemangiomata (Bongiovi and Duffy, 1967).

* Senior Surgical Registrar.

† Formerly Surgical Registrar

¥ Consultant Radiologist.

Westminster Hospital, London SW.1
We report below two cases in which angiomata gave rise to severe intermittent gastrointestinal haemorrhage. In these cases selective visceral arteriography was an invaluable diagnostic method.

\section{Case 1}

A 28-year-old man was admitted to hospital in August 1963 with severe haematemesis and melaena. For 10 years he had had vague dyspepsia for which no cause had been found at a bariummeal examination eight years previously. At the age of 5 years he had been investigated at another hospital for profuse vomiting and some haematemesis which had settled spontaneously.

On examination he was pale and shocked, and the only other physical sign of note was a capillary haemangioma measuring 5 by $2.5 \mathrm{~cm}$. on his face. A Gastrografin contrast study showed no abnormality.

At gastroscopy a small depressed area was seen on the posterior aspect of the lesser curve of the stomach, which was covered by mucus streaked with blood, and he was thought to have haemorrhagic gastritis.

He was readmitted in October 1964 with melaena of one day's duration and exacerbation of dyspepsia for three weeks. As he continued to bleed it was decided to perform a laparotomy. The site of bleeding was found to be an area of greatly thickened angiomatous mucosa high on the lesser curve, and the gastric mucosa elsewhere tended to be hypertrophic and friable. A Billroth I type of gastrectomy was carried out, the lesser curve being resected right up to the cardia. Histology showed a cavernous haemangioma of hamartomatous nature.

He remained well until his readmission with a further haemorrhage in November 1966. Coeliac and superior mesenteric arteriography then showed grossly hypertrophied left gastric and gastroduodenal arteries giving rise to numerous large gastric branches ending in arteriovenous fistulae with early filling of drainage veins (Special Plate, Fig. 1). The gastric mucosa stained heavily with contrast 